\title{
DAYA TERIMA DAN KANDUNGAN ZAT GIZI MIKRO SERABI YANG DIPERKAYA TEPUNG TEMPE DAN TEPUNG IKAN TERI (Stolephorus sp)
}

\author{
, Lydia Fanny ${ }^{1}$, Citra Rahayu ${ }^{2}$, Asmaruddin Pakhri ${ }^{1}$ \\ ${ }^{1}$ Jurusan Gizi, Politeknik Kesehatan Kemenkes, Makassar \\ ${ }^{2}$ Alumni Sarjana Terapan Gizi dan Dietetik Politeknik Kesehatan Kemenkes, Makassar \\ *) citrarahayu@ poltekkes-mks.ac.id/081340141426
}

\begin{abstract}
Children under five begin to have difficulty eating or just like snacks that are classified as empty calories and nutrition in general. Therefore it is necessary to enrich local snacks as an alternative for handling nutritional problems. One of the local snacks that can help improve nutritional problems is serabi with the addition of tempe flour and anchovy flour. This study aims to determine the iron content of serabi with the addition of tempe flour and anchovy flour. This research is a type of laboratory research in the field of food. The serabi formula with the addition of formula concentrations of tempe flour and anchovy flour are F1 (10\%: 5\%), F2 (15\%: 5\%), and F3 (25\%: 5\%). The method of analysis of iron content is AAS (Atomic Absorption Spectrophotometer). The data obtained were analyzed by computer programs using the Friedman test. The results showed that the iron content was highest at a concentration of 10\%: 5\%. The addition of tempe flour and anchovy flour did not have a significant effect on color, aroma, texture and taste. From the most preferred aspect of serabi color on the addition of tempe flour and anchovy flour the concentration of 10\%: 5\% while the most preferred aspects of texture, aroma and taste on the addition of tempe flour and anchovy flour concentration of 10\%: 5\%, 15\%: 5\%, and 25\%: 5\%. It can be concluded that the addition of tempe flour and anchovy flour gives increased levels of iron in the serabi. The addition of tempe flour and anchovy flour do not have a significant effect on color, aroma, texture and taste in all three concentrations.
\end{abstract}

Keywords: Serabi, tempe flour, anchovy flour

\section{PENDAHULUAN}

Kejadian stunting pada balita merupakan salah satu permasalahan gizi secara global. Berdasarkan data UNICEF 2000-2007 menunjukkan prevalensi kejadian stunting di dunia mencapai $28 \%$, di Afrika bagian timur dan selatan sebesar 40\%, dan di Asia selatan sebesar 38\%. Bila dibandingkan dengan batas "non public health problem" menurut WHO untuk masalah stunting sebesar 20\%, maka hampir seluruh negara di dunia mengalami masalah kesehatan masyarakat. Kejadian stunting pada balita lebih banyak terjadi di Negara berkembang. Hal ini dibuktikan dengan prevalensi kejadian stunting pada balita di Negara berkembang sebesar 30\% (UNICEF Report 2009).

Indonesia termasuk di antara 36 negara di dunia yang memberi $90 \%$ kontribusi masalah gizi dunia. Di Indonesia prevalensi stunting pada balita umur 0-59 bulan yaitu 29,6\%, terdiri dari sangat pendek $9,8 \%$ dan pendek $19,8 \%$. Provinsi Sulawesi selatan memiliki prevalensi stunting sebesar $34,8 \%$ yang terdiri dari 
$10,2 \%$ sangat pendek dan $24,6 \%$ pendek (Kemenkes RI, 2017). Sementara target pemerintah dalam penurunan prevalensi stunting pada anak baduta (dibawah 2 tahun) pada tahun 2019 sebesar 28\% (Kemenkes RI, 2015).

Faktor penyebab terjadinya stunting beragam yang mencakup kecukupan zat gizi tidak adekuat dalam jangka waktu panjang dan diperparah dengan terjadinya penyakit infeksi terus menerus (Sudiman, 2008). Salah satu zat gizi yang memegang peran penting adalah zat besi karena berfungsi untuk pertumbuhan dan perkembangan serta memegang peran dalam mengedarkan oksigen ke semua jaringan tubuh. Jika oksigenasi ke jaringan tulang berkurang, maka tulang tidak akan tumbuh maksimal. Sehingga balita yang kekurangan zat besi dapat menyebabkan gangguan kognitif dan fisik serta peningkatan resiko kematian (Petry, 2016).

Alternatif untuk memperbaiki pola konsumsi pangan yang bertujuan untuk menanggulangi masalah gizi yaitu dengan memanfaatkan tempe dan ikan teri karena kandungan gizi yg terkandung di dalamnya. Dilihat dari kandungan protein tempe cukup tinggi dengan nilai PER (Protein Eficiency Ration) yang hampir setara dengan susu sapi dan rendah lemak (Rahmawati, 2013). Kandungan gizi tempe segar per 100 gr yaitu energi $201 \mathrm{kkal}$, protein 20,8 gr, lemak $8,8 \mathrm{gr}$, karbohidrat $13,5 \mathrm{gr}$, serat $1,4 \mathrm{gr}$, kalsium $155 \mathrm{mg}$, fospor $326 \mathrm{mg}$, besi $4 \mathrm{mg}$, natrium $9 \mathrm{mg}$, kalium $234 \mathrm{mg}$, tembaga 0,57 $\mathrm{mg}$, seng 1,7 mg, vitamin B1 0,19 mg, vitamin B2 0,59 $\mathrm{mg}$ dan niasin $4,9 \mathrm{mg}$ (Kemenkes RI, 2018).

Berdasarkan hasil penelitian nilai daya cerna, nilai biologis dan NPU (Net Protein Utilization) untuk tepung tempe tanpa blancing yang dikeringkan pada suhu $50^{\circ} \mathrm{C}$ selama 22 jam beturut-turut $91 \%, 92$, dan 84 (Muchtadi, 1992). Dalam penelitian lainnya pada kue kering kayu manis, substitusi tepung tempe $10 \%$ dapat memberikan sumbungan protein sebesar
3,17\% (1,43gr/100rg kue kering) (Agus, 2008). Dari hasil penelitian menunjukkan selain protein, salah satu zat gizi mikro penting untuk pertumbuhan linier adalah kalsium dan zat besi. Kekurangan kalsium pada anak-anak dan remaja mempengaruhi struktur dasar tulang yang berdampak pada gagalnya pertumbuhan (Singh, 2004). Sedangkan, kekurangan zat besi mempengaruhi tingkat pertumbuhan dan perkembangan anak-anak dan remaja dengan menghambat pertumbuhan linier (Caulfield, 2006). Salah satu sumber kalsium dan zat besi selain susu adalah ikan teri (Stolephorus Sp.) karena ikan teri dikonsumsi utuh bersama tulangnya. Kandungan gizi ikan teri segar per $100 \mathrm{gr}$ yaitu energi $74 \mathrm{kkal}$, protein 10,3 gr, lemak 1,4 gr, karbohidrat 4,1 gr, kalsium 972 mg, fospor 253, besi $3,9 \mathrm{mg}$, natrium $554 \mathrm{mg}$, kalium 126,1 gr, tembaga 302,2 mg, seng 0,2, vitamin A (RE) $28 \mathrm{mcg}$, vitamin B1 0,24 mg, vitamin B2 0,1 mg dan niasin 1,9 mg (Kemenkes RI, 2018).

Hasil penelitian Fanny tahun 2015, didapatkan hasil bahwa hemoglobin pada anak pendek meningkat setelah diberikan abon ikan dan penelitian cookies substitusi tepung tempe $5 \%$ dan tepung ikan teri nasi $10 \%$ dapat memberikan sumbangan protein sebesar $14,57 \%$ per 100 gr. Sedangkan, substitusi tepung tempe $25 \%$ dan tepung ikan nasi $10 \%$ dapat memberikan sumbangan kalsium 53,93mg per 100gr (Rahmawati, 2013). Salah satu produk yang dapat dibuat dari tepung tempe dan tepung ikan teri adalah serabi.

Penelitian ini bertujuan untuk menghasilkan produk jajanan lokal yang dapat memenuhi syarat fisik dan diterima oleh panelis serta memenuhi kebutuhan gizi khususnya zat gizi mikro (Fe) dengan memanfaatkan bahan pangan tempe dan ikan teri sebagai pangan lokal. 


\section{METODE}

\section{Desain, tempat dan waktu}

Desain penelitian yang digunakan adalah Post Test Desain Group. Didalam penelitian ini dilakukan penambahan sejumlah tepung tempe dan tepung ikan teri pada serabi dengan tiga konsentrasi yang berbeda yaitu F1 (10\%:5\%), F2 (15\%:5\%), dan F3 (25\%:5\%). Pembuatan produk serabi dan analisis karakteristik fisik dilakukan di Laboratorium Teknologi Pangan sedangkan analisis karakteristik kimia dilaksanakan di Laboratorium Balai Besar Laboratorium Kesehatan Kota Makassar (Fe). Waktu pelaksanaan penelitian pada bulan Februari - Juni 2019. Bahan dan alat

Bahan yang digunakan dalam penelitian Bubuk instan terdiri atas bahan utama dan bahan pendukung. Bahan utama yaitu tempe, ikan teri, dan tepung beras Tempe dengan karakteristik baik, tidak berwarna hitam, tidak lembek, dan tidak memiliki aroma yang menyengat sedangkan ikan teri dengan karakteristik baik, tidak lembek, tidak berlendir, dan tidak memiliki bau yang meyengat yang diperoleh dari pasar. Bahan pendukung pembuatan serabi dengan penambahan tepung tempe dan tepung ikan teri terdiri atas tepung terigu, gula pasir, ragi bubuk, santan, air, telur, garam, gula merah, ekstrak daun pandan yang diperoleh dari supermarket dan swalayan .

Peralatan yang digunakan dalam penelitian terdiri atas timbangan digital sebagai alat timbang bahan, baskom sebagai wadah pencampuran bahan, kompor dan cetakan kue sebagai alat masak, oven sebagai alat pengering bahan, blender untuk menghancurkan bahan, dan ayakan 60 mesh untuk menghasilkan tepung halus dan alat untuk analisis sifat fisik dan analisis kadar zat besi dengan labu kjeldahl, timbangan analitik, erlenmeyer, pipet skala, tabung sentrifuse, gelas ukur, dan spatula, spektrofotometri.

\section{Langkah-Langkah Penelitian}

Pelaksanaan penelitian meliputi pembuatan tepung tempe, tepung ikan teri, dan pembuatan serabi dengan penambahan formula konsentrasi tepung tempe dan tepung ikan teri. Analisis yang dilakukan adalah analisis karakateristik kimia $(\mathrm{Fe})$, karakteristik organoleptik, dan penentuan formula produk terbaik. Desain penelitian yang digunakan adalah post test group desain. Dilakukan penambahan tepung tempe dan tepung ikan teri pada pembuatan serabi

\section{Pengolahan dan analisis data}

Dilakukan dengan menggunakan program komputer, yaitu dengan pengolahan data SPSS. Sebelum data di input dalam program SPSS data-data tersebut dilakukan proses editing untuk mencegah pemasukan data yang salah.

\section{HASIL}

Pembuatan Formula Serabi Dengan Penambahan Tepung Ikan Tempe dan Tepung Ikan Teri (Stolephorus sp)

Persiapan utama dalam pembuatan serabi pada penelitian ini adalah pembuatan tepung tempe dan tepung ikan teri. Pembuatan tepung tempe diawali dengan pemilihan tempe dengan kualitas yang baik dalam hal ini tidak rusak dan tidak busuk. Setelah itu tempe kemudian dipotong menjadi bagian yang lebih kecil. Setelah dipotong menjadi bagian yang lebih kecil, tempe selanjutnya dikukus selama kurang lebih 20 menit dengan suhu $80^{\circ} \mathrm{C}$. Tempe yang telah dikukus selanjutnya diangkat dan ditiriskan. Setelah itu tempe dikeringkan menggunakan oven dengan suhu $70^{\circ} \mathrm{C}$ selama $10 \mathrm{jam}$. Tempe yang telah kering kemudian dihaluskan menggunakan blender dan layakan. Berat tepung tempe yang akan digunakan dalam penelitian pembuat serabi sebanyak 250 gr.

Bahan selanjutnya adalah pembuatan tepung ikan teri yang diawali dengan sortasi ikan teri. Kemudian ikan dibersihkan dari kotoran (pasir) lalu kemudian ikan yang telah bersih ditimbang, berat mentah ikan 
sebanyak $1 \mathrm{~kg}$. Ikan di rendam dalam air jeruk nipis selama 15 menit kemudian dikukus dengan serai selama 30 menit. ikan teri yang telah dikukus selanjutnya diangkat dan ditiriskan kemudian dikeringkan menggunakan oven dengan suhu $70^{\circ} \mathrm{C}$ selama 8 jam, setelah daging ikan kering kemudian di haluskan menggunakan blender dan diayak menjadi tepung. Selanjutnya tepung di timbang, berat tepung setelah di keringkan yaitu sebanyak 96 gram. Tepung ikan teri selanjutnya dapat digunakan pada penelitian pembuatan serabi.

\section{Pembuatan Serabi dengan Penambahan Konsentrasi Tepung Tempe dan Tepung Ikan Teri}

Pada pembuatan serabi pertamatama santan kental dan air dicampur kemudian dimasak hingga mendidih, lalu didiamkan hingga hangat. Tahapan selanjutnya telur dikocok hingga mengembang lalu dicampur dengan bahan lain yang terdiri dari tepung beras, tepung tempe, tepung ikan teri, tepung terigu, gula pasir, ragi, garam, ekstrak daun pandan, dan santan yang sudah hangat tadi. Semua bahan diaduk-aduk menggunakan pengocok adonan sampai rata dan licin, tidak ada yang bergerindil. Selanjutnya adonan ditutup menggunakan serbet dan didiamkan selama kurang lebih 2 jam. Selanjutnya cetakan kue dipanaskan lalu diberi sedikit minyak goreng. Setelah itu, adonan yang telah didiamkan kemudian dimasak menggunakan cetakan yang telah dipanaskan tadi menggunakan centong sayur. Serabi dimasak menggunakan api kecil hingga masak.

Pada pembuatan kue Serabi yang diperkaya tepung tempe dan tepung ikan teri penambahan tepung ikan tempe dan ikan teri $10 \%$ : $5 \%$ (25gr : 12,5gr) kue yang hasilkan yaitu sebanyak 30 buah, tepung ikan tempe dan ikan teri 15\%:5\% (37,5gr: $12,5 \mathrm{gr})$ sebanyak 32 buah, dan tepung ikan tempe dan ikan teri 25\%: $5 \%(62,5 \mathrm{gr}$ : $12,5 \mathrm{gr})$ sebanyak 36 buah kue.

\section{Daya Terima}

Dalam menilai Komoditi hasil pertanian atau produk olahan serta daya terima masyarakat dilakukan dua pendekatan yaitu objektif dan subjektif. Objektif mengambil keputusan tentang mutu makanan secara fisik, kimia dan mikrobiologi. Sedangkan secara subjektif mutu makanan dapat dinilai secara organoleptik atau dengan menggunakan indera (Zakaria, dkk.2009).

Pada proses uji organoleptik untuk menentukan daya terima panelis sejumlah 30 orang terhadap serabi dengan penambahan tepung tempe dan tepung ikan teri menggunakan panca indera sebagai alat ukur yang menentukan kesukaan panelis. Tingkat kesukaan panelis dilihat dari aspek warna, aroma, tekstur, dan rasa. Tingkat kesukaan dari setiap panelis berbeda-beda sesuai dengan selera masing-masing.

\section{Aspek Warna}

Berdasarkan uji hedonik terhadap aspek warna, serabi dengan penambahan tepung tempe dan ikan teri yang memiliki konsentrasi berbeda dapat dilihat pada tabel 06 berikut. Pada tabel 06. menunjukkan bahwa daya terima tertinggi panelis terhadap aspek warna dari serabi yaitu pada konsentrasi tepung tempe dan tepung ikan teri dengan konsentrasi 15\%:5\% adalah sebanyak 25 panelis (83.3\%) yang suka dan 5 panelis $(16.7 \%)$ yang tidak suka. Sedangkan daya terima terendah serabi yaitu pada konsentrasi tepung tempe dan tepung teri 10\%:5\% adalah sebanyak 23 panelis $(76.7 \%)$ yang suka dan 7 panelis (23.3\%) yang tidak suka. Hasil uji Friedman menunjukkan tidak ada perbedaan pengaruh penambahan tepung tempe dan tepung ikan teri terhadap daya terima dari aspek warna pada serabi dimana nilai sig. 0,267 >0,05. Berdasarkan hasil uji sifat organoleptik serabi dari penambahan tepung tepung tempe dan tepung ikan teri diperoleh nilai median yang tertinggi pada 
konsentrasi 10\%:5\% yaitu nilai median 4 warna. yang menunjukkan konsentrasi 10\%:5\% sangat di sukai oleh panelis dari aspek

Tabel 01.

Distribusi Hasil Daya Terima Serabi Tepung Tempe dan Tepung Ikan Teri Berdasarkan Aspek Warna

\begin{tabular}{llllll}
\hline \multirow{2}{*}{ Serabi } & \multicolumn{4}{c}{ Tingkat Kesukaan Aspek Warna } & \\
\cline { 2 - 5 } & & suka & \multicolumn{2}{c}{ tidak suka } & $\mathrm{p}$ \\
\cline { 2 - 5 } & $\mathrm{n}$ & $\%$ & $\mathrm{n}$ & $\%$ & \\
\hline Konsentrasi 10\%:5\% & 23 & 76.7 & 7 & 23.3 & \\
Konsentrasi 15\%:5\% & 25 & 83.3 & 5 & 16.7 & 0,267 \\
Konsentrasi 25\%:5\% & 24 & 80.0 & 6 & 20.0 & \\
\hline Total & 30 & 100 & 30 & 100 & \\
\hline
\end{tabular}

\section{Aspek Aroma}

Aroma adalah aroma bau yang ditimbulkan oleh rangsangan kimia yang tercium oleh syaraf-syaraf alfaktori yang berada dalam rongga hidung ketika makanan masuk ke dalam mulut (Winarno, 2004). Data kesukaan panelis yang diperoleh sangat beragam dapat dilihat pada tabel 07 berikut. Pada tabel 07. menunjukkan bahwa daya terima tertinggi panelis terhadap aspek aroma dari serabi yaitu pada konsentrasi tepung tempe dan tepung ikan teri 15\%:5\% adalah sebanyak 26 panelis (86.7\%) yang suka dan 4 panelis $(13.3 \%)$ yang tidak suka. Sedangkan daya terima terendah serabi yaitu pada konsentrasi tepung tempe dan tepung ikan teri 25\%:5\% adalah sebanyak 22 panelis (73.3\%) yang suka dan 8 panelis (26.7\%) yang tidak suka. Hasil uji friedman menunjukkan tidak ada perbedaan pengaruh penambahan tepung tempe dan tepung ikan teri terhadap daya terima dari aspek aroma pada serabi dimana nilai sig. $0,557>0,05$. Berdasarkan hasil uji sifat organoleptik serabi dari penambahan tepung tepung tempe dan tepung ikan teri diperoleh nilai median tidak memiliki perbedaan yaitu nilai median 3 .

Tabel 02.

Distribusi Hasil Daya Terima Serabi Tepung Tempe dan Tepung Ikan Teri Berdasarkan Aspek Aroma

\begin{tabular}{|c|c|c|c|c|c|}
\hline \multirow{3}{*}{ Serabi } & \multicolumn{4}{|c|}{ Tingkat Kesukaan Aspek Aroma } & \multirow{3}{*}{$\mathrm{p}$} \\
\hline & \multicolumn{2}{|c|}{ suka } & \multicolumn{2}{|c|}{ tidak suka } & \\
\hline & $\mathrm{N}$ & $\%$ & $\mathrm{~N}$ & $\%$ & \\
\hline Konsentrasi 10\%:5\% & 25 & 83.3 & 5 & 16.7 & \\
\hline Konsentrasi 15\%:5\% & 26 & 86.7 & 4 & 13.3 & 0.557 \\
\hline Konsentrasi 25\%:5\% & 22 & 73.3 & 8 & 26.7 & \\
\hline Total & 30 & 100 & 30 & 100 & \\
\hline
\end{tabular}

Aspek Tekstur

Tekstur merupakan gambaran yang memperlihatkan kekuatan suatu produk makanan dipengaruhi oleh bahan dasar dan 
perlakuan selama proses pengolahan, dimana tekstur mempengaruhi cita rasa yang ditimbulkan oleh bahan tersebut (Winarno, 2004). Tekstur memiliki pengeruh terhadap produk serabi misalnya tingkat kerenyahan, kekerasan, dan sebagainya.

Tabel 03.

Distribusi Hasil Daya Terima Serabi Tepung Tempe dan Tepung Ikan Teri Berdasarkan Aspek Tekstur

\begin{tabular}{llllll}
\hline \multirow{2}{*}{ Serabi } & \multicolumn{4}{c}{ Tingkat Kesukaan Aspek Tekstur } & \\
\cline { 2 - 5 } & & suka & \multicolumn{2}{c}{ tidak suka } & \multirow{2}{*}{$\mathrm{p}$} \\
\cline { 2 - 5 } & $\mathrm{n}$ & $\%$ & $\mathrm{n}$ & $\%$ & \\
\hline Konsentrasi 10\%:5\% & 23 & 76.7 & 7 & 23.3 & \\
Konsentrasi 15\%:5\% & 25 & 83.3 & 5 & 16.7 & 0,952 \\
Konsentrasi 25\%:5\% & 24 & 80.0 & 6 & 20.0 & \\
\hline Total & 30 & 100 & 30 & 100 & \\
\hline
\end{tabular}

Tabel 03. Menunjukkan bahwa daya terima tertinggi panelis terhadap aspek tekstur dari serabi yaitu pada konsentrasi tepung tempe dan tepung ikan teri 15\%:5\% adalah sebanyak 24 panelis $(80.0 \%)$ yang suka dan 4 panelis $(20.0 \%)$ yang tidak suka. Sedangkan daya terima terendah serabi yaitu pada konsentrasi tepung tempe dan tepung ikan teri 10\%:5\% adalah sebanyak 23 panelis $(76.7 \%)$ yang suka dan 7 panelis $(23.3 \%)$ yang tidak suka. Hasil uji Friedman menunjukkan tidak ada perbedaan pengaruh penambahan tepung tempe dan tepung ikan teri terhadap daya terima dari aspek aroma pada serabi dimana nilai sig. 0,952 >0,05. Berdasarkan hasil uji sifat organoleptik serabi dari penambahan tepung tepung tempe dan tepung ikan teri diperoleh nilai median tidak memiliki perbedaan yaitu nilai median 3.

\section{Aspek Rasa}

Daya terima masyarakat terhadap bagea tepung tempe dan tepung ikan teri berdasarkan aspek rasa melibatkan indera pengecap yaitu lidah. Setiap panelis memiliki kesan yang berbeda-beda terhadap aspek rasa dan selera, dengan demikian data kesukaan panelis yang diperoleh sangat beragam dapat dilihat pada table 09 berikut. Pada tabel 09. menunjukkan bahwa daya terima tertinggi panelis terhadap aspek rasa dari serabi yaitu pada konsentrasi tepung tempe dan tepung ikan teri 15\%:5\% adalah sebanyak 29 panelis $(96.7 \%)$ yang suka dan 1 panelis $(3.3 \%)$ yang tidak suka. Sedangkan daya terima terendah serabi yaitu pada konsentrasi tepung tempe dan tepung ikan teri $25 \%: 5 \%$ adalah sebanyak 24 panelis (80.0\%). Hasil uji Friedman menunjukkan tidak ada perbedaan pengaruh penambahan tepung tempe dan tepung ikan teri terhadap daya terima dari aspek rasa pada serabi dimana nilai sig. 0,350 >0,05. Berdasarkan hasil uji sifat organoleptik serabi dari penambahan tepung tepung tempe dan tepung ikan teri diperoleh nilai median tidak memiliki perbedaan yaitu nilai median 3. 
Tabel 04.

Distribusi Hasil Daya Terima Serabi Tepung Tempe dan Tepung Ikan Teri Berdasarkan Aspek Rasa

\begin{tabular}{|c|c|c|c|c|c|}
\hline \multirow{3}{*}{ Serabi } & \multicolumn{4}{|c|}{ Tingkat Kesukaan Aspek Rasa } & \multirow{3}{*}{$\mathrm{p}$} \\
\hline & \multicolumn{2}{|c|}{ suka } & \multicolumn{2}{|c|}{ tidak suka } & \\
\hline & $\mathrm{N}$ & $\%$ & $\mathrm{n}$ & $\%$ & \\
\hline Konsentrasi 10\%:5\% & 25 & 83.3 & 5 & 16.7 & \\
\hline Konsentrasi 15\%:5\% & 29 & 96.7 & 1 & 3.3 & 0,350 \\
\hline Konsentrasi 25\%:5\% & 24 & 80.0 & 6 & 20.0 & \\
\hline Total & 30 & 100 & 30 & 100 & \\
\hline
\end{tabular}

\section{Uji Kadar Zat Besi}

Pemilihan formulasi terbaik pada bagea dengan penambahan tepung tempe dan tepung ikan teri yaitu pada penambahan tepung tempe dan tepung ikan teri $15 \% ; 5 \%$ dan 10\%:5\%. Kandungan gizi pada serabi diuji dengan melakukan analisis kadar zat besi menggunakan metode AAS yang di lakukan di BBLK (Balai Besar Laboratorium Kesehatan Makassar), untuk mengetahui ringkasan hasil pengujian kadar kimia zat besi dalam produk konsentrasi pertama dan konsentrasi kedua resep serabi tersaji pada Tabel 10. Pada tabel 10. tabel menunjukkan bahwa penambahan tepung tempe dan tepung ikan teri pada serabi tidak memberi hasil yang terlalu berbeda terhadap kadar zat besi pada serabi pada konsentrasi pertama dan kedua, dimana setelah dilakukan pengujian dengan dua kali pengulangan atau duoplo didapatkan hasil nilai rata-rata kadar zat besi pada serabi dengan penambahan tepung tempe dan tepung ikan teri pada konsentrasi pertama yaitu $10.62 \mathrm{mg} / \mathrm{gr}$ lebih sedikit lebih tinggi dari hasil nilai rata-rata serabi pada konsentrasi kedua yaitu $10.591 \mathrm{mg} / \mathrm{gr}$.

Tabel 05.

Kandungan Gizi Serabi Dengan Penambahan Tepung Tempe dan Tepung Ikan Teri / Buah (30 Gr)

\begin{tabular}{cccc}
\hline \multirow{2}{*}{ Sampel } & \multicolumn{3}{c}{ Hasil uji Zat gizi Kalsium /mg } \\
\cline { 2 - 4 } & pengulangan & pengulangan & Rata-rata \\
\hline Serabi konsentrasi 10\%:5\% & 1 & 2 & \\
\hline Serabi konsentrasi $15 \%: 5 \%$ & 12.61 & 8.63 & 10.62 \\
\hline
\end{tabular}

\section{PEMBAHASAN}

Tepung tempe adalah produk olahan tempe segar yang mengalami serangkaian proses mulai dari pemilihan bahan, pengukusan, pengeringan, dan terakhir penghalusan tempe kering menjadi tepung tempe. Pembuatan tepung tempe pada penelitian ini digunakan tempe yang dibeli di pasar daya daerah Makassar, Sulawesi Selatan dimana berat mentah tempe dari yang digunakan yaitu 1094 gr setelah melalui proses pengeringan dan penepungan maka didapatkan berat tepung tempe yaitu sebanyak $430 \mathrm{gr}$.

Tepung ikan adalah suatu produk padat yang di hasilkan dengan jalan mengeluarkan sebagian besar cairan dan sebagian atau seluruh lemak yang terkandung di dalam tubuh ikan. Pembuatan tepung ikan pada penelitian ini digunakan 
ikan teri dari daerah Makassar, Sulawesi Selatan dimana berat mentah ikan teri yang digunakan yaitu $1 \mathrm{~kg}$ setelah melalui proses pengeringan dan penepungan maka didapatlah berat tepung ikan teri yaitu sebanyak 96 gr. Pada pembuatan tepung ikan teri pencucian ikan teri bertujuan agar tidak terdapat benda asing dalam hal ini pasir yang ikut dalam proses penepungan.

Serabi merupakan salah satu jenis makanan tradisional khas Jawa yang dikenal cukup luas di Indonesia. Serabi berasal dari bahasa sunda yaitu "sura" yang berarti besar. Serabi memiliki bentuk mirip dengan pancake namun lebih kecil dan tebal. Pembuatan serabi tepung tempe dan tepung ikan teri dilakukan untuk mengetahui berapa komposisi tepung temped an tepung ikan teri yang dapat menghasilkan serabi terbaik. Bagaimana hasil kadar fe dan analisa sensori serabi yang dihasilkan. Dalam penelitian ini dilakukan penambahan tepung tempe dan tepung ikan teri ke dalam serabi dengan konsentrasi tepung tempe dan tepung ikan teri sebagai berikut : $10 \%: 5 \%, 15 \%: 5 \%$, dan $25 \%: 5 \%$. Hasil penelitian menunjukkan bahwa penambahan tepung tempe dan ikan teri yang berbeda dalam pembuatan produk serabi berpengaruh terhadap banyaknya jumlah serabi yang dihasilkan, semakin bertambah tepung tempe dan ikan teri yang dipakai maka semakin banyak pula kue serabi yang dihasilkan juga berpengaruh terhadap hasil uji organoleptik dari aspek warna, aroma, rasa dan tekstur, dengan menggunakan metode hedonik.

Uji kesukaan merupakan faktor terpenting untuk mengetahui penerimaan panelis terhadap suatu produk baik makanan maupun minuman. Suatu produk yang diproduksi sasaran utamanya adalah konsumen jadi salah satu pemenuhan mutu suatu produk tersebut harus dengan kriteria konsumen dimana kenampakan, cita rasa, dan nilai gizi suatu produk merupakan faktor utama.
Menurut Setyaningsih, (2010) bahwa, tujuan analisa sensori adalah sebagai pengujian terhadap bahan makanan berdasarkan kesukaan dan kemauan untuk mempergunakan suatu produk. Dalam penilaian bahan pangan sifat yang menetukan diterima atau tidak suatu produk adalah sifat indrawi

Warna merupakan komponen yang sangat penting untuk menentukan kualitas atau tingkat penerimaan suatu bahan pangan. Suatu bahan pangan meskipun dilinai enak dan teksturnya sangat baik, tetapi memiliki warna yang kurang menarik dipandang atau memberi kesan telah menyimpang dari warna yang seharusnya tidak dikonsumsi. Penentuan mutu suatu pangan pada umumnya tergantung pada warna, karena warna tampil terlebih dahulu (Winarno, 2004).

Berdasarkan hasil penelitian terhadap serabi dengan penambahan tepung tempe dan tepung ikan teri dari aspek warna yang sangat di sukai oleh panelis yaitu konsentrasi 10\%: $5 \%$.

Warna yang dihasilkan dari produk serabi merupakan pengaruh penambahan tepung tempe dan tepung ikan teri. Semakin tinggi tepung tempe dan tepung ikan teri maka warna yang dihasilkan semakin dominan pada warna hijau kecoklatan dan warna yang terbentuk dipengaruhi dari proses pemanggangan. Hal ini sejalan dari hasil penelitian yang telah dilakukan oleh Hestin 2013 bahwa semakin banyak tepung tempe dan tepung ikan teri yang ditambahkan maka warna cookies yang dihasilkan semakin kecoklatan.

Aroma adalah bau yang ditimbulkan oleh rangsangan kimia yang tercium oleh syaraf-syaraf olfaktori yang berada dalam rongga hidung ketika makanan masuk ke dalam mulut (Winarno, 2004). Aroma yang dihasilkan oleh makanan banyak menentukan kelezatan bahan pangan tersebut.

Hasil penelitian menunjukkan bahwa ketiga konsentrasi disukai oleh panelis atau 
tidak memiliki perbedaan, kesukaan panelis terhadap aroma serabi disebabkan penambahan tepung tempe dan tepung ikan teri yang mempunyai aroma yang khas, ditambah aroma kedelai dari tepung tempe yang gurih. Hal ini sejalan dari hasil penelitian yang dilakukan oleh Murano tahun 2003 yang menyatakan aroma dari suatu produk terdeteksi ketika zat yang mudah menguap (volatil) dari produk tersebut terhirup dan diterima oleh sistem penciuman.

Tekstur merupakan gambaran yang memperlihatakan kekuatan suatu produk makanan dipengaruhi oleh bahan dasar dan perlakuan selama prosese pengolahan, dimana tekstur mempengaruhi cita rasa yang ditimbulkan oleh bahan tersebut (Winarno, 2004).

Berdasarkan hasil penelitian menunjukkan bahwa Hasil penelitian menunjukkan bahwa ketiga konsentrasi disukai oleh panelis atau tidak memiliki perbedaan. Hal ini dapat dipengaruhi oleh kadar gluten yang rendah akibat penambahan tepung tempe dan tepung ikan teri. Gluten memiliki sifat fisik yang elastis dan dapat mengembang. Hal ini sejalan dengan penelitian yang dilakukan oleh Sukamto tahun 2006 yang menyatakan rendahnya kandungan gluten mengakibatkan rongga-rongga adonan yang terbentuk hanya sedikit sehingga cookies yang dihasilkan bertekstur keras.

Rasa merupakan salah satu aspek penting dalam menilai kualitas bahan makanan dengan menggunakan indera pengecap. Setiap orang memiliki batasan yang berbeda-beda terhadap suatu produk.

Berdasarkan hasil penelitian menunjukkan bahwa ketiga konsentrasi disukai oleh panelis atau tidak memiliki perbedaan, pada penambahan tepung tempe dan tepung ikan teri diduga memiliki proporsi rasa gurih tepung tempe yang tepat yang diimbangi shortening maupun rasa gurih yang ditimbulkan dari tepung ikan teri dan santan kelapa sehingga akan membantu memperbaiki cita rasa pada produk serabi tepung tempe dan tepung ikan teri. Hal ini sesuai dengan pernyataan (Winarno, 2004), bahwa Fungsi shortening adalah untuk memperbaiki cita rasa, struktur, tekstur, keempukan dan memperbesar volume kue.

Serabi dengan penambahan tepung tempe dan tepung ikan teri memiliki kandungan zat besi sehingga dengan mengkonsumsi produk serabi bisa menambah asupan zat besi dalam tubuh karena zat besi berfungsi untuk pertumbuhan dan perkembangan (Petry,2016). Selain itu zat besi memiliki beberapa fungsi esensial di dalam tubuh: sebagai alat angkut oksigen dari paru-paru ke jaringan, sebagai alat angkut elektron di dalam sel dan sebagai bagian terpadu berbagai reaksi enzim di dalam tubuh (Almatsier, 2002).

Dari hasil penelitian menunjukkan selain protein, salah satu zat gizi mikro penting untuk pertumbuhan linier adalah kalsium dan zat besi. Kekurangan kalsium pada anak-anak dan remaja mempengaruhi struktur dasar tulang yang berdampak pada gagalnya pertumbuhan (Singh, 2004). Sedangkan, kekurangan zat besi mempengaruhi tingkat pertumbuhan dan perkembangan anak-anak dan remaja dengan menghambat pertumbuhan linier (Caulfield, 2006). Salah satu sumber kalsium dan zat besi selain susu adalah ikan teri (Stolephorus Sp.) karena ikan teri dikonsumsi utuh bersama tulangnya.

Salah satu tujuan dari pengembangan jajanan lokal serabi dengan penambahan tepung tempe dan tepung ikan teri ini adalah untuk meningkatkan nilai gizi zat besi yang dimana jika dikonsumsi oleh balita dapat memenuhi sebagian atau semua kebutuhan zat besi pada balita sehingga menjadi alternative untuk penanggulang stunting.

\section{KESIMPULAN}

Formula bahan serabi dengan penambahan tepung tempe dan tepung ikan 
teri dimana tepung tempe yang dihasilkan dalam penelitian ini berwarna kream, memiliki aroma, rasa, kenampakan menyerupai tepung tempe pada umumnya. Sedangkan tepung ikan teri yang dihasilkan dalam penelitian ini berwarna abu-abu, memiliki aroma, rasa, kenampakan, menyerupai tepung ikan pada umumnya.

Serabi tepung tempe dan tepung ikan teri yang dihasilkan dalam penelitian ini berbentuk bulat, memiliki aroma dan rasa perpaduan yang khas antara ikan teri dan kedelai warna hijau yang didapat dari ekstrak daun pandan dan kenampakan yang khas serabi pada umumnya.

Produk terbaik dari hasil organoleptik berdasarkan empat aspek penilaian ialah serabi tepung tempe dan ikan teri dengan konsentrasi 10\%:5\%.

Zat besi dalam produk serabi dari hasil uji zat besi didapatkan hasil terbaik yaitu serabi dengan konsentrasi 10\%:5\% yaitu dengan rata-rata nilai zat besi 10.62 $\mu \mathrm{g} / \mathrm{g}$.

\section{SARAN}

serabi $\begin{array}{r}\text { Sebaiknya dilakukan pembuatan } \\ \text { dengan perlakuan }\end{array}$ menggunakan konsentrasi tepung ikan teri yang berbeda-beda untuk melihat secara jelas perbedaan tingkat kadar zat besi dari masing-masing sampel serta penelitian mengenai umur masa simpan serabi.

\section{DAFTAR PUSTAKA}

Agus S \& M Sulchan. 2008. Pengaruh Subsitusi Tepung Terigu dengan Tepung Tempe dan Tepung Bekatul terhadap Kadar Protein, Kadar Serat dan Daya Terima Kue Kering Kayu Manis. Skripsi. Jurusan Gizi Universitas Diponegoro.

Almatsier, S. 2002. Prinsip Dasar Ilmu Gizi. Jakarta: PT. Gramedia Pustaka Utama.

Caulfield, LE., Stephanie, AR., Juan, AR.,
Philip, M., Robert, EB. 2006. Stunting, Wasting, and Micronutrient Deficiency

Disorders in Disease Control Priorities in Developing Countries, World Bank. Washington DC.

Fanny L. 2015. The Effect of Fishmeal on the Levels of Zinc,Vitamin A Serum, Nutritional Intake and Shortness Status of Children Aged 2-4 Years after Administration of Vitamin $A$ in Makassar, South Sulawesi, Indonesia. International Journal of Sciences: Basic and Applied Research (IJSBAR). Volume 24 (6) pp 426-432.

Kementrian Kesehatan RI. 2015. Rencana Pemerintah Jangka Menengah Nasional 2015-2019. Kementrian Kesehatan Republik Indonesia.

Kementrian Kesehatan RI. 2017. Buku Saku Pemantauan Status Gizi dan Indikator Kinerja Gizi Tahun 2017. Kementrian Kesehatan Republik Indonesia.

Kementrian Kesehatan RI. 2018. Data Komposisi Pangan Indonesia. Kementrian Kesehatan Republik Indonesia.

Muchtadi. 2010. Ilmu Pengetahuan Bahan Pangan. Bogor: Alfabeta

Murano, Peter S. 2003. Understanding Food Science And Tecnology. USA: Thomson Wadwonth, hal 420-449.

Petry N, Olofin I, Boy E, Angel MD, Rohner F. 2016. The Effect of Low Dose Iron and Zinc Intake on Child Micronutrient Status and Development during the First 1000 Days of Life: A Systematic and Meta-Analysis. Nutrients. Volume 773 (8).

Rahmawati, H dan Ninik R. 2013. Pengaruh Substitusi Tepung 
Tempe dan Substitusi Tepung

Ikan Teri Nasi Terhadap

Kandungan Protein, Kalsium,

dan Organoleptik Cookies.

Jurnal Teknologi dan Industri

Pangan. Volume 2 (3).

Singh M. 2004. Role of Micronutrients for Physical Growth and Mental Development. Indian Journal Pediatric. Volume 71.

Sukamto. 2006. Perbaikan Tekstur dan Sifat Organoleptik Roti yang dari Bahan Baku Tepung Jagung Dimodifikasi Oleh Gum Xanthan. Skripsi. Universitas Widyagama Malang.

[UNICEF] United Nation International Children's Emergency Fund. 2009. Annual Report 2009. UNICEF Division Communication, New York, USA.

Winarno, FG. 2004. Kimia Pangan dan Gizi: Edisi Terbaru. Jakarta: Gramedia Pustaka Utama.

Zakariah, Salmiah, Chaerunnimah, Nursalim. 2009. Bahan Ajar Ilmu Teknologi Pangan. Makassar, Jurusan Gizi Politeknik Kesehatan Kemenkes Makassar. 